\title{
Presence of Adrenocorticotropin-Potentiating Factors in Porcine Thyroid Glands
}

\author{
Keiko Matsuyama, Kaname MORIWAKi, Sayomi IIDA, Yoshiharu ITOH, \\ Masahiro GOMI, Shuji KAWAMURA and SeIIChIro TARUI
}

\author{
The Second Department of Internal Medicine, Osaka University \\ Medical School Fukushima-ku, Osaka 553
}

\begin{abstract}
An extract of porcine thyroid gland in $0.1 \mathrm{~N}$ acetic acid exerted dosedependent potentiation of ACTH-induced corticosterone production in isolated rat adrenal cells. The extract by itself manifested no steroidogenic activity.

Upon gel-filtration of the extract, potentiating activities were demonstrated in three main peaks with molecular weights of about 10,000, 5,000 and 2,000. These findings indicate the presence of heterogeneous forms of ACTH-potentiating factors in the thyroid. Significant enhancement of ACTH-induced steroidogenesis was readily apparent with three gel-filtration fractions at a lower concentration of ACTH (4.75 pM). At this concentration, dose-dependent potentiation was observed with these three fractions.

Enhanced corticosterone production responses by cells preincubated with the thyroid extract were observed and the results indicated the existence of potentiating mechanisms other than inhibition of ACTH proteolysis.

The lack of $\mathrm{T}_{4}, \mathrm{~T}_{3}$ and thyroglobulin in this activity suggests that the activity resides in other constituents of the thyroid.
\end{abstract}

We recently demonstrated the presence of ACTH-potentiating factors (APF) in rat anterior pituitary glands (Iida et al., 1981) and in porcine thymus (Iida, et al., 1984). This factor had an augmenting effect on steroidogenesis in the presence of a minute amount of synthetic adrenocorticotropin (ACTH) in isolated rat adrenal cells, in vitro. In addition, we reported on the presence of APF in a calcitonin preparation derived from porcine thyroid glands (Iida et al., 1982a). The observation results strongly suggest that APF might also be present in the thyroid gland.

The major focus of this study was to

Received March 9, 1984 demonstrate the presence of APF in porcine thyroid glands, and, in addition, by gel filtration, to partially characterize their action mechanism and nature.

\section{Materials and Methods}

The ACTH preparation used was corticotropin-(1-24)-tetracosapeptide [ACTH-(1-24); Cortrosyn ${ }^{\circledR}$; Daiichi Pharmaceutical Co., Tokyo, Japan]. $T_{4}$ and $T_{3}$ were purchased from Sigma; human thyroglobulin was prepared by the method described by Van Herle et al. (1973).

Preparation of Tissue Extracts and Gel Filtration Two porcine thyroid glands weighing $17 \mathrm{~g}$ were obtained in an ice-chilled container from a 
slaughterhouse within two hours of sacrifice. The glands were chopped into small pieces, boiled in $50 \mathrm{ml}$ of $0.1 \mathrm{~N}$ acetic acid for $20 \mathrm{~min}$ and homogenized. After centrifugation at $1000 \times \mathrm{g}$, the supernatant was collected.

For gel filtration, $1.5 \mathrm{ml}$ of the supernatant was applied on a column $(90 \times 1.5 \mathrm{~cm})$ of BioGel P-10. Elution was carried out with $0.1 \mathrm{~N}$ acetic acid in fractions of $9 \mathrm{ml}$.

Extract and fraction protein concentrations were determined by the method developed by Lowry et al. (1951).

\section{Bioassay}

Bioassay procedures, including preparation of isolated adrenal cells by the method described by Sayers et al. (1971) and corticosterone determination by the competitive protein binding method developed by Murphy (1967) were followed as previously described (Iida et al., 1981) using ACTH-(1-24) as a standard. Cells were suspended $8-15 \times 10^{4}$ cells $/ \mathrm{ml}$ in Krebs-Ringer bicarbonate buffer containing glucose $(200 \mathrm{mg} /$ $100 \mathrm{ml}$ ) and $1.5 \%$ bovine serum albumin. Cell viabilities ranged between 90 and $95 \%$ as determined by trypan blue. A Teflon plate containing 96 wells, $5 \mathrm{~mm}$ in diameter, each holding up to $200 \mu \mathrm{l}$ of fluid, was used for the incubation. Samples were distributed in the wells and dried in vacuum. Buffer solutions, $20 \mu \mathrm{l}$ with or without ACTH-(1-24), and $50 \mu \mathrm{l}$ of cell suspension were mixed and incubated. Incubation was performed under $95 \% \mathrm{O}_{2}$ and $5 \% \mathrm{CO}_{2}$ at $37^{\circ} \mathrm{C}$ with shaking at 100 cycles/min for $2 \mathrm{~h}$. Incubation was terminated by transferring $50 \mu \mathrm{l}$ of the medium, including cells, to a test tube containing $0.2 \mathrm{ml}$ of ethanol. The mixture was then evaporated to dryness in vacuum and corticos- terone measured.

Each assay contained seven standard curve concentrations of ACTH-(1-24) (from 0.4 to 40 $\mathrm{pg} /$ well; performed in triplicate). The mean correlation coefficient for the standard curves for ACTH-(1-24) (4.75-47.5 pM), obtained from 12 experiments, was 0.974 (range, 0.945-0.987). The mean intra-assay variation for ACTH-(1-24) $(19.0 \mathrm{pM})$, which was tested in quintuplicate in the same assay, was $8.6 \%$ (range, 2.1-11.5\%). The significance of differences between means within the same assay was analyzed using Student's $t$-test.

\section{Results}

\section{Effects of Thyroid Extract on ACTH-induced} Steroidogenesis

Thyroid extract had little influence on steroidogenesis at concentrations of 10 or $26 \mu \mathrm{g}$ of protein $/ \mathrm{ml}$. However, steroidogenesis was markedly increased, in a dosedependent manner, by adding thyroid extracts to $4.75 \mathrm{pM}$ of ACTH-(1-24) (Table 1). This potentiating activity was observed at all concentrations of ACTH tested (1.9 to $190 \mathrm{pM}$ ) (Fig. 1).

\section{Gel Filtration Profiles of the Extract}

Fig. 2 shows the gel filtration profiles for the thyroid extract. When $50 \mu$ aliquot of each fraction was dried in vacuum and assayed for biological ACTH activity, marginal activity appeared in those fractions

Table 1. Effect of thyroid extracts on steroidogenetic action of ACTH-(1-24) in isolated rat adrenal cells.

\begin{tabular}{lcc}
\hline \hline \multirow{2}{*}{ Additions } & \multicolumn{2}{c}{ Corticosterone production $\left(\mathrm{ng} / 10^{4}\right.$ cells $\left.\cdot 2 \mathrm{~h}\right)$} \\
\cline { 2 - 3 } & None & ACTH-(1-24) $(4.75 \mathrm{pM})$ \\
\hline None & N.D. & $3.3 \pm 0.8$ \\
Thyroid extract & & \\
$10 \mu \mathrm{g}$ of protein $/ \mathrm{ml}$ & N.D. & $38.4 \pm 3.5^{\mathrm{a}, \mathrm{b}}$ \\
$26 \mu \mathrm{g}$ of protein $/ \mathrm{ml}$ & N.D. & $49.4 \pm 2.6^{\mathrm{a}, \mathrm{b}}$ \\
\hline
\end{tabular}

Values represent mean $\pm \mathrm{SE}$ of 6 determinations on corticosterone production $\left(\mathrm{ng} / 10^{4}\right.$ cells $\left.\cdot 2 \mathrm{~h}\right)$

N.D., not detectable.

ap $<0.005$ vs. $4.75 \mathrm{pM}$ ACTH-(1-24) only.

$\mathrm{b} p<0.005$ vs. thyroid extract only. 

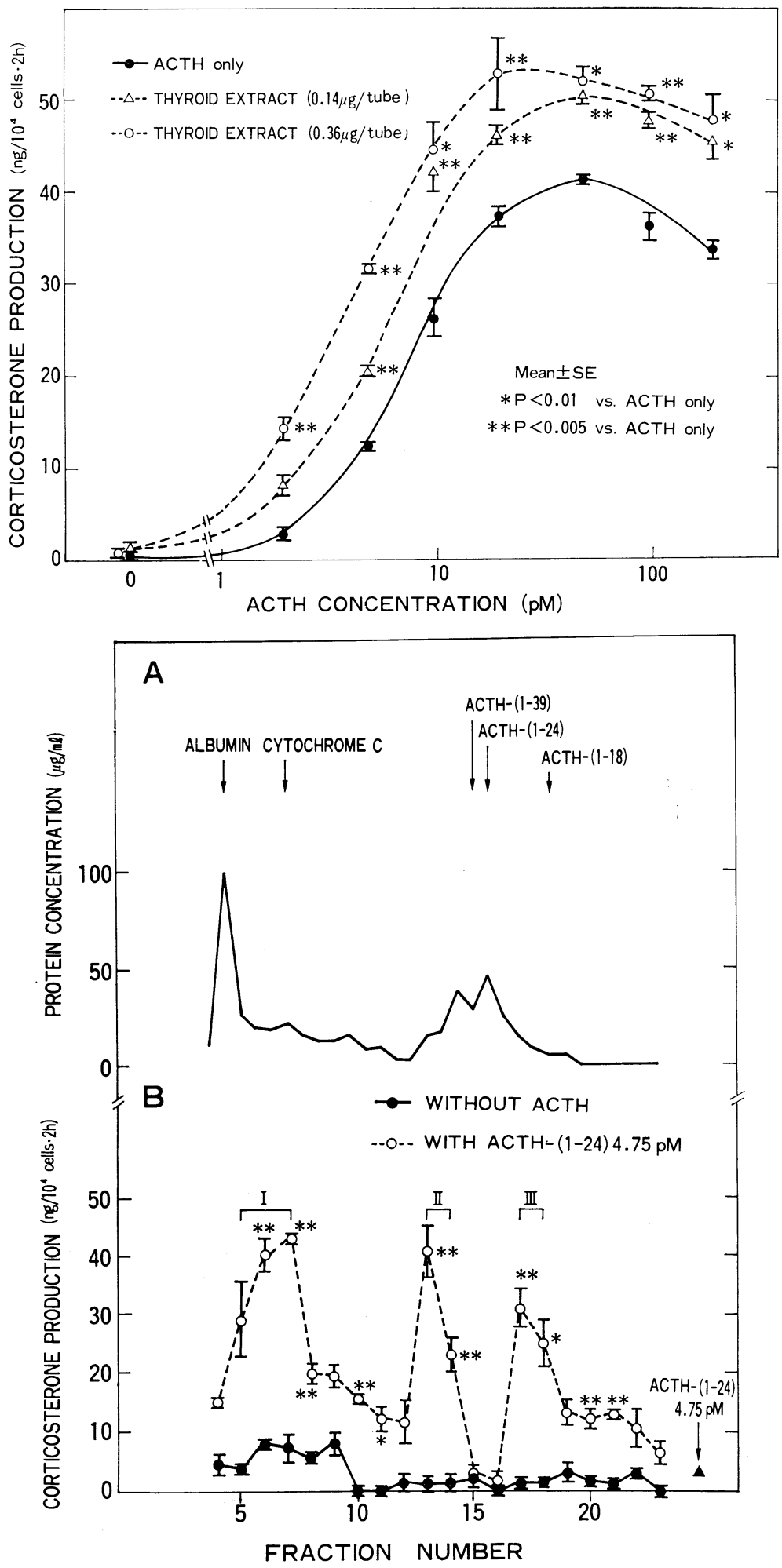

Fig. 1. Isolated rat adrenal cell dose-response curves to ACTH-(1-24), with or without thyroid extracts. Each data point is the mean of triplicate determinations. The vertical bars indicate \pm SEM. $=\mathrm{ACTH}-(1-24)$ alone; $\triangle--\triangle=$ ACTH-(1-24) plus thyroid extract $(0.14 \mu \mathrm{g}$ of protein / tube); $\mathrm{O}--\mathrm{O}=$ ACTH-(1-24) plus thyroid extract $(0.36 \mu \mathrm{g}$ of protein tube).

${ }^{*} \mathbf{P}<0.01$ vs. ACTH only. $* \mathrm{P}<0.005$ vs. ACTH only.

Fig. 2. Gel filtration of porcine thyroid extract on a $90 \times 1.5 \mathrm{~cm}$ column of Bio-Gel P-10 (see text). A : Concentrations of protein. The elution positions for albumin, cytochrome C, ACTH-(1-39), ACTH-(124) and ACTH-(1-18) are indicated. B: Steroidogenesis with or without ACTH-(1-24); - $\bullet=$ without $\mathrm{ACTH}, \mathrm{O}-\mathrm{O}=$ with 4.75pM ACTH-(1-24).Each data point is a mean of triplicate determinations; the vertical bars indicate \pm SEM.

$* \mathbf{P}<0.01$ vs. without ACTH.

$* * \mathbf{P}<0.005$ vs. without ACTH. 
with higher molecular weights. By adding 4.75 pM ACTH, marked increases in steroidogenesis were observed in three main peaks. These peaks were named fractions I, II and III, respectively, in their order of elution. Fractions I, II and III had molecular weights of about 10,000, 5,000 and 2,000, respectively.

\section{Dose-action Relationship of the Potentiating} Effects of the Gel Filtration Fractions

Fig. 3 shows the dose-action relationships of each fraction in the absence or presence of $4.75 \mathrm{pM}$ of ACTH-(1-24). Dose-dependent potentiation of ACTH action is readily apparent for all three fractions.

Effects of Gel Filtration Fractions on Steroidogenesis Induced with Various Concentrations of $A C T H$

Fig. 4 shows effects of the three fractions on corticosterone production at different concentrations of ACTH-(1-24). Significant potentiation was observed at lower concentrations of ACTH (1.9 pM and $4.75 \mathrm{pM}$ for fraction III and $4.75 \mathrm{pM}$ for fractions I and II). At higher concentrations of ACTH(1-24) (19 pM and $47.5 \mathrm{pM}$ ), fraction III inhibited steroidogenesis significantly.

\section{Effect of Preincubation with Thyroid Extract} of Adrenal Cells

As shown in Table 2, preincubation of the cells with the thyroid extract resulted in potentiation of corticosterone production with 19 and 47.5 pM ACTH-(1-24).

Effects of $T_{4}, T_{3}$ and Thyroglobulin on ACTHinduced Steroidogenesis

$\mathrm{T}_{4}, \mathrm{~T}_{3}$, and thyroglobulin possessed no ACTH-potentiating activity. Thyroglobulin at a concentration of $0.29 \mu \mathrm{g} / \mathrm{ml}$ rather inhibited steroidogenesis in the presence of 4.75pM ACTH (Table 3).

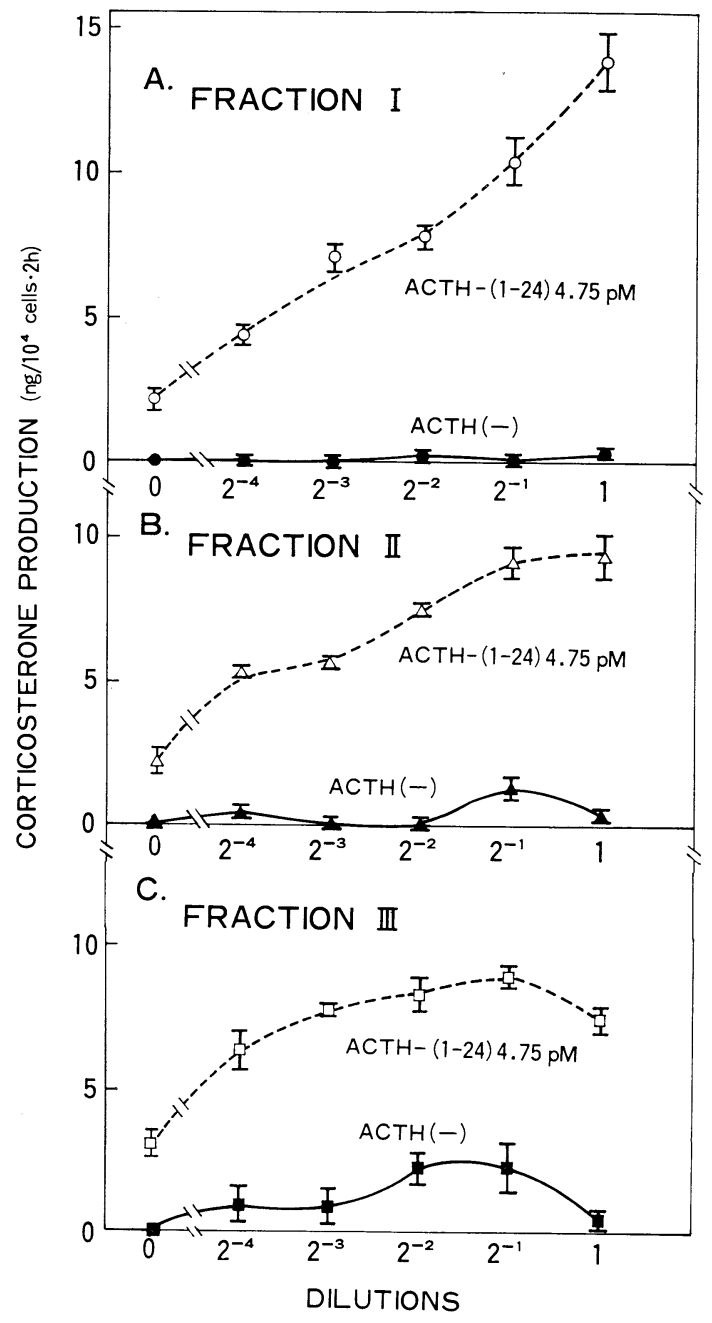

Fig. 3. Dose-action relationship of potentiating effects of gel filtration fractions of thyroid extract on ACTH-induced steroidogenesis. These fractions (I, II and III) were obtained as described in Materials and Methods ; Five twofold dilution series of the three fractions were tested for biological ACTH activity as well as for ACTH-potentiating activity. The original protein concentrations of fractions I, II and III were $37.3,9.6$ and $5.8 \mu \mathrm{g} / \mathrm{ml}$, respectively. A : Fraction I. Absence (๑) or presence (O) of $4.75 \mathrm{pM}$ ACTH-(1-24). B: Fraction II. Absence $(\Delta)$ or presence $(\triangle)$ of $4.75 \mathrm{pM}$ ACTH(1-24). C: Absence ( $\square$ ) or presence ( $\square$ ) of $4.75 \mathrm{pM}$ ACTH-(1-24). Vertical bars indicate \pm SEM of triplicate determinations. 


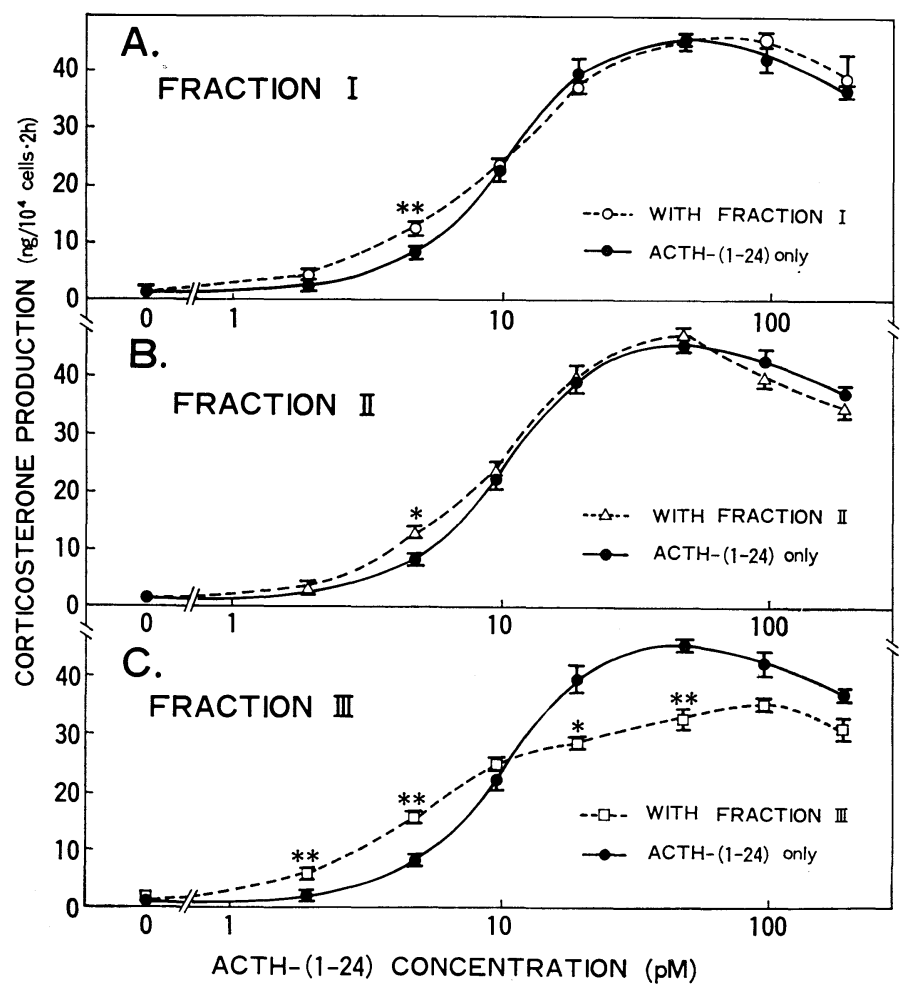

Fig. 4. Dose response curves of isolated rat adrenal cells to ACTH-(1-24) with or without gel filtration fractions. A: Fraction I (1.8 $\mu \mathrm{g}$ of protein/well). B: Fraction II $(0.5 \mu \mathrm{g}$ of protein/well). C: Fraction III $(0.3 \mu \mathrm{g}$ of protein/well). $\bullet--\bullet$ ACTH-(1-24) only; $\mathrm{O}--\mathrm{O}=\mathrm{ACTH}-(1-24)$ plus fraction I; $\Delta^{--} \triangle=$ ACTH(1-24) plus fraction II; $\square--\square=$ ACTH-(1-24) plus fraction III. Each data point is the mean of triplicate determinations; the vertical bars indicate \pm SEM.

$* \mathrm{P}<0.05$ vs. ACTH-(1-24) only.

$* * \mathbf{P}<0.01$ vs. ACTH-(1-24) only.

Table 2. Effect of preincubation with thyroid extract of adrenal cells on ACTHinduced steroidogenesis.

\begin{tabular}{|c|c|c|c|}
\hline \multirow{3}{*}{ Treatment } & \multicolumn{3}{|c|}{ Corticosterone production $\left(\mathrm{ng} / 10^{4}\right.$ cells $\left.\cdot 2 \mathrm{~h}\right)$} \\
\hline & \multicolumn{2}{|c|}{ ACTH-(1-24) } & $(\mathrm{pM})$ \\
\hline & 0 & 19 & 47.5 \\
\hline $\begin{array}{l}\text { Control } \\
\text { Preincubation with } \\
\text { Thyroid extract }\end{array}$ & $\begin{array}{l}\text { N.D. } \\
\text { N.D. }\end{array}$ & $\begin{array}{l}27.1 \pm 1.1 \\
36.7 \pm 1.9 \mathrm{a}\end{array}$ & $\begin{array}{l}37.3 \pm 2.7 \\
58.3 \pm 4.1^{b}\end{array}$ \\
\hline
\end{tabular}

Values represent mean $\pm \mathrm{SE}$ of quadruplicate determinations on corticosterone production $\left(\mathrm{ng} / 10^{4}\right.$ cells $\left.\cdot 2 \mathrm{~h}\right)$. N.D., not detectable. Cells were preincubated with or without thyroid extract $(18 \mu \mathrm{g}$ of protein $/ \mathrm{ml})$ for $15 \mathrm{~min}$ and washed after centrifugation. Cells were resuspended in assay buffer and incubated for a further $2 \mathrm{~h}$.

ap $<0.005$ vs. control.

$\mathrm{b} p<0.01$ vs. control. 
Table 3. Effects of $\mathrm{T}_{4}, \mathrm{~T}_{3}$, and thyroglobulin on steroidogenic action of ACTH(1-24) in isolated rat adrenal cells.

\begin{tabular}{lcc}
\hline \hline \multirow{2}{*}{ Additions } & \multicolumn{2}{c}{ Corticosterone Production $\left(\mathrm{ng} / 10^{4}\right.$ cells $\left.\cdot 2 \mathrm{~h}\right)$} \\
\cline { 2 - 3 } & None & ACTH-(1-24) $(4.75 \mathrm{pM})$ \\
\hline None & N.D. & $4.6 \pm 0.7$ \\
$\mathrm{~T}_{4}(\mu \mathrm{g} / \mathrm{ml})$ & & \\
$2.85 \times 10^{-1}$ & N.D. & $6.8 \pm 1.3$ \\
2.85 & N.D. & $3.3 \pm 1.1$ \\
$2.85 \times 10$ & N.D. & $5.9 \pm 0.9$ \\
$\mathrm{~T}_{3}(\mu \mathrm{g} / \mathrm{ml})$ & & \\
$2.85 \times 10^{-3}$ & N.D. & $3.8 \pm 0.5$ \\
$2.85 \times 10^{-2}$ & N.D. & $3.3 \pm 0.7$ \\
$2.85 \times 10^{-1}$ & N.D. & $4.9 \pm 0.6$ \\
Thyroglobulin $(\mu \mathrm{g} / \mathrm{ml})$ & & \\
$2.85 \times 10^{-3}$ & N.D. & $5.7 \pm 0.8$ \\
$2.85 \times 10^{-2}$ & N.D. & $4.4 \pm 1.4$ \\
$2.85 \pm 10^{-1}$ & N.D. & $1.3 \pm 0.8^{\mathrm{a}}$ \\
\hline
\end{tabular}

Values represent mean $\pm \mathrm{SE}$ of triplicate determinations on corticosterone production $\left(\mathrm{ng} / 10^{4}\right.$ cells 2 h). N.D., not detectable.

${ }^{a} \mathrm{p}<0.005$ vs. $4.75 \mathrm{pM}$ ACTH-(1-24) only.

\section{Discussion}

Pedersen and Brownie (1980a) reported initial evidence indicating the presence of ACTH-potentiating activity in the $16 \mathrm{~K}$ fragment (the aminoterminal region of proACTH/endorphin precursor prepared from mouse pituitary tumor cell line AtT-20D $16 v^{\prime}$ ) as well as in its trypsin-treated fragment in vitro. They further demonstrated that $\gamma_{3}$ MSH had the same activity in vivo (Pedersen and Brownie, 1980b). Similar results were also reported for the $16 \mathrm{~K}$-fragment using perifusion of adrenal cells (Al-Dujaili et al., 1981).

In earlier and more recent studies, using isolated rat adrenal cells, we suggested that APF were present in heterogenous forms as to molecular weight in extracts of rat anterior pituitary (Iida et al., 1981) and porcine thymus (Iida et al., 1984). Recently, we demonstrated that a commercially available calcitonin preparation contained ACTHpotentiating activity (Iida et al., 1982a).
Since synthetic eel calcitonin was devoid of this activity (Iida et al., 1982b), our findings strongly suggest that APF might be present in thyroid glands from which the calcitonin preparations were derived.

The present study clearly demonstrates the presence of APF in acid extracts of porcine thyroid glands. Upon gel filtration of the extracts, these activities were detected in three fractions. These data are closely in concert with previous findings made on calcitonin preparations by Iida et al. (1982a). $\mathrm{T}_{3}, \mathrm{~T}_{4}$ and thyroglobulin had virtualy no effect on ACTH-induced steroidogenesis (Table 3). Therefore, it would appear that the ACTH-potentiating activity resided in other constituents of the thyroid.

Our present data, however, are somewhat in contrast to our previous observations made on APF from rat anterior pituitaries. Thyroid extracts have so far stimulated corticosterone production over the wide range of ACTH concentrations tested (Fig. 1), while the pituitary APF exerted its effect only at lower concentrations. An explanation for this difference is not readily avail- 
able. When the extract was subjected to gel filtration and fractionated into three fractions, each fraction, as shown in Fig. 4, exhibited potentiation similar to that observed with pituitary APF. At present it is not clear why fraction III inhibited steroidogenesis induced with higher concentrations of ACTH (from 19 to $47.5 \mathrm{pM}$ ).

Iida et al. (1981) observed the potentiating effect of pituitary APF on ( $\mathrm{Ibu}^{1}$, Lys $\left.{ }^{17-19}\right)$ ACTH-(1-19) nonadecapeptide amide, which has been shown to be less susceptible to proteolytic degradation. We postulated the existence of potentiating mechanisms other than the inhibition of ACTH proteolysis. This is further supported by our present demonstration of potentiation by preincubation of the cells with thyroid extract (Table 2).

Since simultaneous neoplasm production of ACTH and calcitonin is well known, it is possible that the thyroid contains ACTH/ lipotropin precursors, although radioimmunoassayable ACTH was not detected in the extract (data not presented here). Identification of those ACTH-potentiating activities found in thyroid glands, as distinct from those in the pituitary, must await further studies.

\section{Acknowledgements}

The authors are indebted to Misses $Y$. Takahashi, T. Horio, and Y. Moriyama for their technical assistance. We also thank Prof. J. White, Tezukayama Gakuin College, Osaka Japan, for his through revision of the manuscript.

\section{References}

Al-Dujaili, E.A.S., J. Hope, F. E. Estivariz, P. J. Lowry and C. R. Edwards (1981). Circulating human pituitary pro- $\gamma$-melanotropin enhances the adrenal response to ACTH. Nature 291, $156-159$.

Iida, S., Y. Itoh, K. Moriwaki, S. Tarui and F. Kawakami (1981). Presence of ACTH-potentiating factors in rat anterior pituitary glands. Horm. Res. 14, 155-164.

Iida, S., Y. Itoh and K. Moriwaki (1982a). Presence of adrenocorticotropin-potentiating activity in a calcitonin preparation derived from porcine thyroid glands. Pharmacology 24, 211-214.

Iida, S., K. Matsuyama, Y. Itoh, K. Moriwaki, S. Tarui and F. Kawakami (1982b). Augmentation of ACTH-induced steroidogenesis in isolated rat adrenal cells by rat tissue extracts and by hormone preparations. Endocrinol. Japon. 29, 251-254.

Iida, S., Y. Itoh, M. Gomi, K. Moriwaki and S. Tarui (1984). Partial characterization of ACTH-potentiating factors derived from porcine thymus. Horm. Res. (in press).

Lowly, O. H., N. J. Rosebrough, A. L. Farr and R. J. Randcell (1951). Protein measurement with the Folin phenol reagent. J. Biol. Chem. 193, 265-275.

Murhy, B. E. P. (1967). Some studies of the protein-binding of steroids and their application to the routine micro and ultamicro measurement of various steroids in body fluids by competitive protein-binding radioassay. $J$. Clin. Endocrinol. Metab. 27, 973-990.

Pedersen, R. C. and A. C. Brownie (1980a). Adrenocortical response to corticotropin is potentiated by part of the aminoterminal region of pro-corticotropin/endorphin. Proc. Natl. Acad. Sci. USA 77, 2239-2243.

Pedersen, R. C. and A. C. Brownie (1980b). Proadrenocorticotropin endorphin derived peptides coordinate action on adrenal steroidogenesis. Science 208, 1044-1045.

Sayers, G. and R. L. Swallow (1971). An improved technique for the preparation of isolated rat adrenal cells: A sensitive, accurate and specific method for the assay of ACTH. Endocrinology 88, 1063-1068.

Van Herle, A. J., R. P. Uller, N. L. Matthew and J. Brown (1973). Radioimmunoassay for measurement of thyroglobulin in human serum. J. Clin. Invest. 52, 1320-1327. 